\title{
DIVERSITY OF GENETIC RESOURCES AND GENETIC ASSOCIATION ANALYSES OF GREEN AND DRY CHILLIES OF EASTERN INDIA
}

\author{
Arup Chattopadhyay ${ }^{*}$, Amit Baran Sharangi ${ }^{2}$, Nuka Dai ${ }^{2}$, and Subrata Dutta ${ }^{1}$
}

\begin{abstract}
Chilli (Capsicum annuum L.) is regarded as one of the main commercial vegetable and spice crops at the global level. Maximum diversity can be noted among the cultivars/landraces available in India with respect to shape, size, yield, quality, and other traits. The present experiment was conducted to identify the most promising chilli variety suited for green and dry purposes, to study the genetic variability for different traits and to assess the association of different yield attributing traits with the green and dry yield of chilli. Thirty four genotypes were characterized during a 2-yr period. Most of the genotypes possessed the character constellation of $C$. annuum. Two genotypes, 'Chaitali Pointed' and 'BC CH Sel-4' were found most promising with respect to green fruit yield (272.79 g, $221.10 \mathrm{~g}$ per plant) and dry fruit yield (54.56 g, $44.44 \mathrm{~g}$ per plant). Phenotypic and Genotypic Coefficient of Variation values for green fruit weight $(119.95 \%, 111.26 \%)$, green fruit girth $(89.76 \%, 48.93 \%)$, weight of red ripe fruit $(112.02 \%, 111.93 \%)$, weight of dry fruit $(111.63 \%, 110.97 \%)$ and number of fruits per plant $(86.05 \%, 85.02 \%)$ were recorded to be high. Green fruit yield per plant, ascorbic acid content, and number of fruits per plant also showed very high broad-sense heritability and genetic advance. From the study of correlation and path coefficient analyses, the number of fruits per plant, green fruit length for green chilli, weight of dry fruit and the number of fruits per plant for dry chilli were found to the most important selection indices.
\end{abstract}

Key words: Quantitative traits, qualitative traits, genetic variability, heritability, selection index, Capsicum annuum.

$\mathrm{I}_{\mathrm{L}}^{\mathrm{n}}$ dia is one of the leading chilli (Capsicum annuum L.) producing countries of the world. It is grown for for use as a vegetable (green chilli), spice (dry chilli), condiment, sauce and pickle under tropical, sub-tropical and temperate climates (Hazra et al., 2011). Chilli, both in the green and ripe stages, is an important condiment used for imparting pungency, which is due to an active principle 'capsaicin', an alkaloid present in the placenta, which can directly scavenge various free radicals (Reddy and Lokesh, 1992; Kogure et al., 2002; Bhattacharya et al., 2010). Chilli is considered a good source of vitamin C (ascorbic acid) in food and beverage industries (Bosland and Votava, 1999). It has also acquired a great importance because of the presence of 'oleoresin', which permits better distribution of color and flavor in foods.

Though India stands first in chilli cultivation, representing $45 \%$ of the world acreage, its productivity is quite low ( $1 \mathrm{t} \mathrm{ha}^{-1}$ dry chilli) as compared to USA, China, South Korea, Taiwan, etc. (3-4 t ha ${ }^{-1}$ dry chilli) as reported by Reddy et al. (2002). The main reason for

${ }^{1}$ All India Coordinated Research Project on Vegetable Crops, Directorate of Research, Bidhan Chandra Krishi Viswavidyalaya, Kalyani-741235, Nadia, West Bengal, India.

"Corresponding author (chattopadhyay.arup@gmail.com).

${ }^{2}$ Faculty of Horticulture, Department of Spices and Plantation Crops, Bidhan Chandra Krishi Viswavidyalaya, Mohanpur-741252, Nadia, West Bengal, India.

Received: 15 March 2011.

Accepted: 5 June 2011 low productivity in India is the use of open pollinated varieties, with only $2.6 \%$ of cultivated areas using hybrid varieties (Hundal, 2000).

In spite of tremendous potential use, good scope for export as a spice, high nutritive value, good acceptability among the average Indian farmer and consumer, and a wide range of available genetic variability, India is still far behind in attaining the required optimum productivity in chilli. Moreover, all the available information regarding the quality parameters has been confined to a few genotypes with very scanty data available for parameters like capsaicin, ascorbic acid, and oleoresin contents. Therefore, concentrated efforts are necessary to improve yield and yield components. Hence, evaluation of the potential of existing genetic resources in eastern India is essential because improvement programs depend on the genetic diversity of the crop. The magnitude of heritable, and more particularly genetic components, is clearly the most important aspect of the genetic constitution of the breeding material, which has a close bearing on its response to selection. Selection of one trait invariably affects a number of associated traits, which evokes the necessity to determine the interrelationship of various yield components, both among themselves and with yield. Keeping in view the above facts, the present experiment was undertaken with the following two objectives: To evaluate and characterize different qualitative and quantitative characters of chilli genotypes grown in Eastern India; and to study character inter-relationships 
and their direct and indirect effects on green and dry chilli fruit yield.

\section{MATERIALS AND METHODS}

\section{Plant material}

The present investigation was undertaken during the autumn-winter season of two consecutive years (20082009 and 2009-2010) at "C" Block Farm at the research field of the All India Coordinated Research Project on Vegetable Crops, Bidhan Chandra Krishi Viswavidyalaya, Kalyani, Nadia, West Bengal, India. This site (22 $2^{\circ} 56^{\prime} \mathrm{N}$, $88^{\circ} 32^{\prime}$ E, 9.75 m.a.s.l.) is situated in a humid sub-tropical region with an average temperature range of 11.25 to $29.25^{\circ} \mathrm{C}$ during the autumn-winter months (SeptemberMarch). The soil of the experimental field was sandy loam in texture, with good drainage and medium soil fertility. Thirty-four genotypes collected from different parts of Eastern States (West Bengal, Assam, Tripura, Bihar, Orissa, and Eastern UP) of India were evaluated following a randomized complete block design with three replicates. The seedlings of each genotype were raised under low cost poly tunnel. Nursery beds were covered with 200 $\mu \mathrm{m}$ ultraviolet (UV)-stabilized film supported by bamboo poles with open sides to protect seedlings from rain and direct sunlight. The sides of the nursery structure were covered with a 50 mesh nylon net to prevent the attack of whitefly (Bemisia tabaci). Seedlings were hardened by withholding water $4 \mathrm{~d}$ before transplanting. Twentyfive-day-old, seedlings, at least $15 \mathrm{~cm}$ in height with 3-4 leaves, were used for transplanting in the main field, at a spacing of $50 \mathrm{~cm}$ both ways in a plot size of $9 \mathrm{~m}^{2}$. The crop was fertilized with $15 \mathrm{t}$ farmyard manure, along with $120 \mathrm{~kg} \mathrm{~N} \mathrm{ha}^{-1}$ (Urea), $60 \mathrm{~kg} \mathrm{P}_{2} \mathrm{O}_{5}$ ha $^{-1}$ (Single super phosphate) and $60 \mathrm{~kg} \mathrm{~K}_{2} \mathrm{O}$ ha $^{-1}$ (potassium chloride). 1/3 amount of $\mathrm{N}$ and full doses of $\mathrm{P}$ and $\mathrm{K}$ were applied at planting. The remaining amount of $\mathrm{N}$ was top-dressed at $30 \mathrm{~d}$ after planting (DAP) and 60 DAP in equal amounts. The cultural practices were followed in accordance with Bose et al. (2003).

\section{Physical-chemical characteristics}

Each genotype was characterized regarding 16 morphological characters in accordance with the descritptor list of the International Plant Genetic Resources Institute in Rome. Ten randomly selected plants from each replicate were taken to record ten quantitative and three qualitative traits. One plant out of each genotype was kept for selfing to collect selfed seeds for the next generation. Selfing was done by covering the plant with a cage of mesh size $20 \times 16$ holes per $2.5 \mathrm{~m}^{2}$ (Bosland and Votava, 1999) to prevent insect pollination. Vitamin C content was determined by the dichlorophenol indophenol titration procedure (Casanas et al., 2002). For analysis of capsaicin, $0.5 \mathrm{~g}$ of dry chilli powder was extracted with $10 \mathrm{~mL}$ dry acetone (acetone free from water obtained after treatment with anhydrous $\mathrm{Na}_{2} \mathrm{SO}_{4}$ ) by shaking for $3 \mathrm{~h}$ in a mechanical shaker, the contents centrifuged at $10000 \mathrm{~g}$ for $10 \mathrm{~min}$, and the supernatant evaporated to dryness in a hot water bath. The residue was re-dissolved in $5 \mathrm{~mL} 0.4 \%$ sodium hydroxide solution and $3 \mathrm{~mL} \mathrm{3 \%}$ phosphomolybdic acid solution. The contents were shaken by hand and kept aside for $1 \mathrm{~h}$ and then centrifuged at $5000 \mathrm{~g}$ for $15 \mathrm{~min}$ and the absorbance of the blue color supernatant measured at $650 \mathrm{~nm}$ against a reagent blank. The content of capsaicin was calculated using a calibration curve against a high purity capsaicin (Sadasivam and Manickam, 1992). The oleoresin content of ripe red fruits was estimated in accordance with the method of Ranganna (1986).

\section{Statistical analysis}

The mean data obtained were used to determine a genotypic coefficient of variation and a phenotype coefficient of variation (Burton, 1952), broad-sense heritability (Hanson et al., 1956), and the expected genetic advance (Johnson et al., 1955). The correlation coefficients at the genotypic and phenotypic levels were calculated in accordance with the method given by Johnson et al. (1955). The path coefficient analysis was done in accordance with Dewey and $\mathrm{Lu}$ (1959). All statistical analyses were done using SPSS Professional Statistics version 7.5 (SPSS Inc., Chicago, Illinois, USA).

\section{RESULTS AND DISCUSSION}

\section{Characterization of chilli genotypes}

Sixteen morphological characters were recorded in accordance with the descriptors and their frequency distribution patterns as shown in Table 1. The genotypes showed three plant growth habits. It was observed that $53 \%$ of the genotypes showed intermediate plant growth habit, 38\% showed erect habit and only $9 \%$ had spreading habit. The predominant branching habits were dense, sparse and intermediate with $41 \%, 32 \%$ and $27 \%$ of genotypes, respectively. Maximum genotypes (74\%) had medium-sized leaves and the rest had small to large leaves. The pigmentation at nodes was mostly present (88\%) in the genotypes. Most of the genotypes (82\%) had lanceolate shaped-leaves. The predominant leaf color was green (77\%). All the genotypes had only one flower per axil, except one that had more than two flowers per axil. The predominant anther color was blue (32\%), followed by purple (26\%), bluish yellow, and pale blue. Entire and intermediate type calyx margins were observed in equal proportion (38\%), followed by a dentate type (24\%). Most of the genotypes (80\%) had long fruit shape, followed by conical and very long. Maximum genotypes (91\%) showed pendant fruit position and the remaining were in erect position. The fruit shape of most of the genotypes at blossom-end was pointed (65\%) and the remaining ones showed a blunt-type fruit shape. The 
Table 1. Frequency distribution pattern for morphological characters in chilli genotypes.

\begin{tabular}{|c|c|c|c|}
\hline Characters & Specification & $\begin{array}{c}\mathrm{N}^{\circ} \text { of } \\
\text { genotypes }\end{array}$ & $\begin{array}{c}\% \text { of } \\
\text { genotypes }\end{array}$ \\
\hline \multirow[t]{3}{*}{ Plant growth habit } & Intermediate & 18 & 52.94 \\
\hline & Spreading & 3 & 8.83 \\
\hline & Erect & 13 & 38.23 \\
\hline \multirow[t]{3}{*}{ Branching habit } & Dense & 14 & 41.17 \\
\hline & Sparse & 11 & 32.36 \\
\hline & Intermediate & 9 & 26.47 \\
\hline \multirow[t]{3}{*}{ Leaf size } & Small & 2 & 5.89 \\
\hline & Medium & 25 & 73.52 \\
\hline & Large & 7 & 20.59 \\
\hline \multirow[t]{2}{*}{ Leaf shape } & Ovate & 6 & 17.65 \\
\hline & Lanceolate & 28 & 82.35 \\
\hline \multirow[t]{3}{*}{ Leaf color } & Green & 26 & 76.48 \\
\hline & Dark green & 4 & 11.76 \\
\hline & Light green & 4 & 11.76 \\
\hline \multirow[t]{2}{*}{ Pigment at node } & Absent & 4 & 11.76 \\
\hline & Present & 30 & 88.24 \\
\hline \multirow[t]{2}{*}{$\mathrm{N}^{\circ}$ of flowers per axil } & More than two & 1 & 2.95 \\
\hline & One & 33 & 97.05 \\
\hline \multirow[t]{2}{*}{ Fruit surface } & Smooth & 5 & 14.70 \\
\hline & Wrinkled & 29 & 85.30 \\
\hline \multirow[t]{3}{*}{ Fruit shape at pedicel attachment } & Acute & 1 & 2.94 \\
\hline & Obtuse & 29 & 85.30 \\
\hline & Truncate & 4 & 11.76 \\
\hline \multirow[t]{4}{*}{ Anther color } & Bluish yellow & 7 & 20.59 \\
\hline & Pale blue & 7 & 20.59 \\
\hline & Blue & 11 & 32.36 \\
\hline & Purple & 9 & 26.46 \\
\hline \multirow[t]{3}{*}{ Calyx margin } & Intermediate & 13 & 38.23 \\
\hline & & 8 & 23.54 \\
\hline & Entire & 13 & 38.23 \\
\hline \multirow[t]{3}{*}{ Immature fruit color } & Green & 29 & 85.30 \\
\hline & Light green & 3 & 8.83 \\
\hline & Dark green & 2 & 5.87 \\
\hline \multirow[t]{6}{*}{ Ripe fruit color } & Dark red & 4 & 11.76 \\
\hline & Red & 21 & 61.75 \\
\hline & Light red & 1 & 2.95 \\
\hline & Orange & 4 & 11.76 \\
\hline & Pale orange & 1 & 2.95 \\
\hline & Brown & 3 & 8.83 \\
\hline \multirow[t]{2}{*}{ Fruit position } & Pendant & 31 & 91.17 \\
\hline & Erect & 3 & 8.83 \\
\hline \multirow[t]{3}{*}{ Fruit shape } & Conical & 4 & 11.76 \\
\hline & Long & 27 & 79.41 \\
\hline & Very long & 3 & 8.83 \\
\hline \multirow[t]{2}{*}{ Blossom end fruit shape } & Pointed & 22 & 64.70 \\
\hline & Blunt & 12 & 35.30 \\
\hline
\end{tabular}

predominant immature fruit color was green $(85 \%)$ and ripe fruit color was red (62\%). Most of the genotypes $(85 \%)$ had an obtuse fruit shape at the pedicel attachment. From the morphological study, it is established that most of the genotypes possess the character constellation of $C$. annuиm and only one genotype (Ganga Kaveri-1) belongs to $C$. frutescens.

The genotypes showed a wide range of variation in different yield component traits (Table 2). The earliest $50 \%$ flowering was noted in genotype Cob chilli-10 (30.33 d) followed by 'Cob chilli-3' (30.67 d), 'HP-30' and 'HP-33' (31.00 d). However, very late flowering was observed in chilli-335 $(109.00 \mathrm{~d})$. The green fruit weight of the genotypes varied between $1.60 \mathrm{~g}$ and $23.00 \mathrm{~g}$, the maximum being in HP-30 followed by genotypes HP-25 $(20.67 \mathrm{~g})$. Green fruit length was the maximum in 'HP-25' $(14.97 \mathrm{~cm})$ and the minimum in 'chilli-335' $(2.93 \mathrm{~cm})$. The range of values was comparable to observations of
Rani (2001). The green fruit girth varied from 0.53 to $2.77 \mathrm{~cm}$. The results are in line with those observed by Chandra et al. (1990). The weight of red ripe fruit weight varied considerably, ranging from 1.07 to $19.87 \mathrm{~g}$. The maximum weight of dry fruit was found in 'HP-30' (4.60 g) and the minimum in 'Beldanga' $(0.20 \mathrm{~g})$. The number of fruits per plant ranged from 5.6 to 134.0. The maximum number of fruits per plant was recorded in 'BC Ch Sel-4' and the minimum in 'HP-30'. The number of seeds per fruit varied from 43.33 to 117 . The green fruit yield per plant varied considerably, ranging from 41.80 to 272.79 $\mathrm{g}$. The maximum green fruit yield per plant was obtained in 'Chaitali pointed' followed by 'BC Ch Sel-4'. The range of values was in agreement with the observations of previous works (Chandra et al., 1990; Singh et al., 2005; Tembhurne et al., 2008). The mean ratio of green fruit yield to dry fruit yield per plant was 4.87:1. The results corroborate the earlier findings of Sheela et al. (2004), who observed 20.25 to $25.61 \%$ recovery of dry chilli from the green ones. The maximum dry fruit yield per plant was noted in 'Chaitali pointed' $(54.56 \mathrm{~g})$ and the minimum was recorded in 'Cob chilli- 8 ' (8.36 g). The same trend of results were obtained by earlier works (Rani, 2001; Singh et al., 2005).

The quality characters of different chilli genotypes are shown in Table 3. The range of ascorbic acid content in green fruit, which agrees with Khadi et al. (1987), was highest for the genotype BCC-1 (221.18 mg $\left.100 \mathrm{~g} \mathrm{~g}^{-1}\right)$ and the lowest for the genotype Cob chilli-8 (9.93 mg $\left.100 \mathrm{~g}^{-1}\right)$. The capsaicin content of ripe fruit was estimated to be high in 'BCC-12' (0.37\%), followed by 'BCC-1' $(0.31 \%)$ and 'BCC-62' $(0.26 \%)$, with a mean value of $0.15 \%$, which agrees well with the observations of Gomez-Fuentes and Canessa (1988). The oleoresin content of ripe fruit varied from $8.89 \%$ to $37.00 \%$, the maximum being in 'AC-588' and the minimum in 'BCC-12'.

\section{Assessment of genetic variability and heritability}

The ANOVA for the different yield component characters revealed that the mean square due to genotypes was highly significant. The phenotypic coefficient of variance (PCV) agreed closely with the values of the genotypic coefficient of variance (GCV). However, the value of the PCV is slightly greater than that of the GCV for all the characters (Table 4). The results obtained by Bandale et al. (2006) follow the same trends. The PCV and GCV values for green fruit weight, green fruit girth, weight of red ripe fruit, weight of dry fruit, and number of fruits per plant were high and the broad-sense heritability value of most of the characters was high (96.5 to $99.80 \%$ ). This trend is in line with values obtained by Khurana et al. (2003). The genetic advance (GA), which is expressed as a percentage of mean was very high for characters like green fruit yield per plant (122.97), ascorbic acid content (102.60), and number of fruits per plant (74.75), which had high value of broad-sense heritability, indicating 
Table 2. Yield component characters of 34 chilli genotypes.

\begin{tabular}{|c|c|c|c|c|c|c|c|c|c|c|}
\hline Genotypes & $\begin{array}{c}\text { Days to } \\
50 \% \\
\text { flowering } \\
\end{array}$ & $\begin{array}{c}\text { Green } \\
\text { fruit } \\
\text { weight }\end{array}$ & $\begin{array}{c}\text { Green } \\
\text { fruit } \\
\text { length }\end{array}$ & $\begin{array}{l}\text { Green } \\
\text { fruit } \\
\text { girth }\end{array}$ & $\begin{array}{l}\text { Weight } \\
\text { of ripe } \\
\text { fruit }\end{array}$ & $\begin{array}{l}\text { Weight } \\
\text { of dry } \\
\text { fruit }\end{array}$ & $\begin{array}{l}\text { Number of } \\
\text { fruits per } \\
\text { plant }\end{array}$ & $\begin{array}{l}\text { Number } \\
\text { of seeds } \\
\text { per fruit }\end{array}$ & $\begin{array}{c}\text { Green fruit } \\
\text { yield per } \\
\text { plant }\end{array}$ & $\begin{array}{c}\text { Dry fruit } \\
\text { yield per } \\
\text { plant } \\
\end{array}$ \\
\hline & & $\mathrm{g}$ & \multicolumn{2}{|c|}{$\longrightarrow \mathrm{cm} \longrightarrow$} & \multicolumn{2}{|c|}{$\longrightarrow \mathrm{g}$} & & & & \\
\hline BCC-1 & 88.00 & 2.90 & 4.76 & 1.12 & 1.32 & 0.27 & 65.25 & 64.00 & 189.00 & 37.80 \\
\hline BC Ch Sel-4 & 62.00 & 1.63 & 6.23 & 1.20 & 1.39 & 0.33 & 134.00 & 74.00 & 221.10 & 44.22 \\
\hline BCC-12 & 40.00 & 2.27 & 5.47 & 1.10 & 1.18 & 0.26 & 53.33 & 69.33 & 75.27 & 15.05 \\
\hline BCC-62 & 45.00 & 1.60 & 9.20 & 1.10 & 1.39 & 0.32 & 90.67 & 116.33 & 147.92 & 29.58 \\
\hline BCC -30 & 75.00 & 1.67 & 7.39 & 0.87 & 1.27 & 0.25 & 80.24 & 57.00 & 131.00 & 26.20 \\
\hline AC-575 & 71.00 & 1.72 & 6.63 & 0.90 & 1.62 & 0.35 & 69.07 & 59.33 & 124.26 & 24.85 \\
\hline AC-576 & 38.00 & 7.47 & 6.63 & 1.30 & 6.67 & 1.49 & 11.00 & 60.67 & 87.18 & 17.44 \\
\hline AC-585 & 43.00 & 1.80 & 5.20 & 0.33 & 1.23 & 0.36 & 63.67 & 54.00 & 116.90 & 23.38 \\
\hline AC-588 & 44.00 & 2.76 & 8.07 & 0.83 & 2.57 & 0.55 & 19.00 & 63.33 & 59.88 & 11.98 \\
\hline AC- 615 & 39.00 & 3.43 & 6.23 & 0.60 & 2.53 & 0.69 & 36.67 & 74.67 & 133.26 & 26.65 \\
\hline HP-25 & 40.00 & 20.67 & 14.97 & 1.87 & 17.53 & 4.12 & 6.47 & 83.00 & 137.42 & 27.48 \\
\hline HP-26 & 44.00 & 6.63 & 9.87 & 1.17 & 5.23 & 1.33 & 27.67 & 43.33 & 189.81 & 37.96 \\
\hline HP-27 & 32.00 & 12.87 & 11.17 & 2.13 & 11.77 & 2.57 & 6.77 & 112.67 & 89.10 & 17.82 \\
\hline HP-30 & 31.00 & 23.00 & 11.47 & 2.77 & 19.87 & 4.60 & 5.60 & 22.67 & 129.56 & 25.91 \\
\hline HP-33 & 31.00 & 8.20 & 11.27 & 1.40 & 5.17 & 1.64 & 19.33 & 94.33 & 128.83 & 25.77 \\
\hline Chaitali pointed & 56.00 & 2.22 & 6.30 & 1.20 & 1.97 & 0.44 & 114.40 & 79.00 & 272.79 & 54.56 \\
\hline Chaitali Blunt & 85.00 & 2.00 & 3.53 & 0.92 & 1.12 & 0.22 & 55.30 & 65.40 & 110.00 & 22.45 \\
\hline Beldanga & 86.00 & 1.60 & 7.76 & 0.84 & 1.07 & 0.20 & 56.20 & 55.80 & 83.00 & 16.80 \\
\hline Mukta & 76.00 & 1.67 & 7.78 & 0.83 & 1.24 & 0.24 & 90.00 & 77.60 & 148.60 & 29.70 \\
\hline J. Mukta & 57.00 & 1.70 & 8.03 & 0.90 & 1.64 & 0.34 & 89.00 & 94.00 & 171.49 & 34.30 \\
\hline Chandramukhi & 77.00 & 3.30 & 6.87 & 0.89 & 2.68 & 0.53 & 23.00 & 56.00 & 75.47 & 15.07 \\
\hline Ganga Kaveri-1 & 52.00 & 2.10 & 6.53 & 0.90 & 1.82 & 0.43 & 76.67 & 84.00 & 172.41 & 34.48 \\
\hline Aismali & 42.00 & 2.12 & 4.53 & 0.53 & 1.84 & 0.42 & 59.67 & 52.67 & 129.99 & 26.00 \\
\hline Sel-14 & 90.00 & 1.67 & 4.73 & 0.63 & 1.35 & 0.30 & 91.00 & 73.00 & 152.00 & 38.00 \\
\hline Barshali & 46.00 & 2.00 & 2.93 & 0.95 & 1.65 & 0.41 & 32.00 & 56.00 & 65.00 & 17.20 \\
\hline Chilli-335 & 109.00 & 1.67 & 2.93 & 0.93 & 1.65 & 0.41 & 32.00 & 56.00 & 65.00 & 17.20 \\
\hline Chilli-353 & 75.33 & 2.43 & 6.16 & 0.82 & 1.25 & 0.31 & 42.03 & 55.50 & 103.00 & 25.75 \\
\hline Cob chilli-1 & 55.67 & 2.87 & 7.03 & 1.43 & 2.74 & 0.57 & 62.00 & 54.67 & 190.95 & 38.19 \\
\hline Cob chilli-2 & 71.67 & 1.81 & 7.00 & 0.63 & 1.66 & 0.37 & 72.67 & 72.67 & 133.58 & 26.71 \\
\hline Cob chilli-3 & 30.67 & 2.27 & 4.23 & 0.63 & 2.04 & 0.45 & 22.00 & 52.67 & 57.48 & 11.50 \\
\hline Cob chilli-6 & 54.67 & 1.83 & 12.00 & 1.20 & 1.70 & 0.40 & 25.80 & 47.67 & 47.21 & 9.40 \\
\hline Cob chilli-8 & 31.67 & 2.07 & 3.27 & 1.30 & 2.08 & 0.41 & 18.67 & 73.67 & 41.80 & 8.36 \\
\hline Cob chilli-10 & 30.33 & 2.48 & 4.63 & 1.10 & 2.38 & 0.50 & 17.00 & 86.00 & 42.16 & 8.43 \\
\hline Cob chilli-11 & 41.33 & 2.12 & 4.33 & 1.13 & 2.01 & 0.43 & 26.00 & 117.00 & 63.88 & 12.78 \\
\hline Average & 55.60 & 4.07 & 6.91 & 1.07 & 3.80 & 0.87 & 49.18 & 69.35 & 120.18 & 24.67 \\
\hline $\operatorname{LSD}(\mathrm{P}=0.05)$ & 4.80 & 1.41 & 0.40 & 0.22 & 0.44 & 0.28 & 11.54 & 6.27 & 12.17 & 2.44 \\
\hline $\mathrm{CV}, \%$ & 5.24 & 12.39 & 2.69 & 9.06 & 4.44 & 12.12 & 13.28 & 4.17 & 5.10 & 5.10 \\
\hline
\end{tabular}

$\mathrm{CV}$ : coefficient of variation (ratio of the standard deviation to the mean).

a preponderance of additive gene action for the control of these traits. Thus, selection based on these characters would be effective. These observations are supported by earlier workers (Bhagyalakshmi et al., 1990; Rani et al., 1996; Gogoi and Gautam, 2002; Das and Maurya, 2004; Prabhakaran et al., 2004; Varkey et al., 2005; Wasule et al., 2007; Patel et al., 2009).

\section{Correlation coefficient}

Association analysis of different morphological characters with green and dry fruit yield of chilli and their inter-relationships were investigated through the study of both phenotypic and genotypic correlation coefficient. In the present study, eight characters including growth and reproductive characters were recorded and their genotypic and phenotypic correlation coefficients were analyzed for green chilli (Table 5) and seven characters were analyzed for dry chilli (Table 6). For both green and dry chillies, the phenotypic and genotypic correlation coefficient, in general, agreed very closely.

Three characters, namely days to $50 \%$ flowering, number of fruits per plant, and ascorbic acid content, exhibited significantly positive correlation coefficients with green fruit yield per plant. Hence selection based on these characters would be rewarding. These findings corroborate the earlier observations of Bhagyalakshmi et al. (1990); Rani (1997); Devi and Aramugam (1999); Kumar et al. (2003); Nandadevi and Hosamani (2003); Tembhurne et al. (2008). However, green fruit weight, green fruit girth, and number of seeds per fruit exhibited negative correlations with green fruit yield per plant. The correlation between green fruit yield and green fruit length was non-significant, although positive, indicating its limited contribution towards green fruit yield per plant.

However, two characters days to $50 \%$ flowering and number of fruits per plant exhibited significantly positive correlation coefficient with dry fruit yield per plant. The other characters exhibited negative correlations with dry fruit yield per plant.

\section{Path coefficient analysis}

In the present study, the phenotypic correlation was partitioned into direct and indirect effects to identify the relative importance of yield components towards green and dry fruit yield of chilli genotypes (Tables 5 and 6).

Among the seven yield attributing characters, number 
Table 3. Quality characters of 34 chilli genotypes.

\begin{tabular}{|c|c|c|c|}
\hline Genotypes & $\begin{array}{l}\text { Ascorbic acid } \\
\text { content of } \\
\text { green fruit }\end{array}$ & $\begin{array}{c}\text { Capsaicin } \\
\text { content } \\
\text { of ripe fruit }\end{array}$ & $\begin{array}{l}\text { Oleoresin } \\
\text { content of } \\
\text { ripe fruits }\end{array}$ \\
\hline & $\mathrm{mg} 100 \mathrm{~g}^{-1}$ & $\longrightarrow$ & 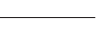 \\
\hline BCC-1 & 221.18 & 0.31 & 22.25 \\
\hline BC Ch Sel-4 & 131.32 & 0.12 & 31.00 \\
\hline BCC-12 & 21.38 & 0.37 & 8.89 \\
\hline BCC- 62 & 128.36 & 0.26 & 10.83 \\
\hline BCC-30 & 89.25 & 0.17 & 17.26 \\
\hline AC-575 & 52.81 & 0.14 & 31.00 \\
\hline AC-576 & 55.22 & 0.16 & 20.22 \\
\hline AC-585 & 32.65 & 0.11 & 22.00 \\
\hline AC-588 & 130.08 & 0.10 & 37.00 \\
\hline AC- 615 & 150.02 & 0.12 & 10.83 \\
\hline HP-25 & 123.29 & 0.20 & 30.67 \\
\hline HP-26 & 108.43 & 0.21 & 26.00 \\
\hline HP-27 & 79.41 & 0.11 & 11.83 \\
\hline HP-30 & 125.92 & 0.20 & 31.00 \\
\hline HP-33 & 17.47 & 0.20 & 22.00 \\
\hline Chaitali pointed & 132.74 & 0.13 & 11.67 \\
\hline Chaitali Blunt & 105.32 & 0.11 & 12.00 \\
\hline Beldanga & 115.40 & 0.15 & 18.26 \\
\hline Mukta & 146.32 & 0.15 & 12.42 \\
\hline J. Mukta & 168.10 & 0.13 & 11.33 \\
\hline Chandramukhi & 48.26 & 0.11 & 9.53 \\
\hline Ganga Kaveri-1 & 97.66 & 0.10 & 11.00 \\
\hline Aismali & 53.25 & 0.11 & 29.17 \\
\hline Sel-14 & 128.20 & 0.11 & 27.00 \\
\hline Barshali & 27.24 & 0.10 & 12.24 \\
\hline Chilli-335 & 34.56 & 0.10 & 12.24 \\
\hline Chilli-353 & 32.00 & 0.10 & 23.50 \\
\hline Cob chilli-1 & 20.86 & 0.13 & 11.17 \\
\hline Cob chilli-2 & 68.64 & 0.13 & 24.93 \\
\hline Cob chilli-3 & 67.34 & 0.08 & 24.67 \\
\hline Cob chilli-6 & 35.67 & 0.11 & 18.00 \\
\hline Cob chilli-8 & 9.93 & 0.13 & 31.15 \\
\hline Cob chilli-10 & 55.28 & 0.16 & 23.33 \\
\hline Cob chilli-11 & 32.75 & 0.24 & 12.80 \\
\hline Average & 83.71 & 0.15 & 19.68 \\
\hline $\operatorname{LSD}(\mathrm{P}=0.05)$ & 0.90 & 0.02 & 2.06 \\
\hline $\mathrm{CV}, \%$ & 0.56 & 5.66 & 4.81 \\
\hline
\end{tabular}

CV: coefficient of variation (ratio of the standard deviation to the mean).

of fruits per plant and green fruit length showed highly positive direct effects on green fruit yield per plant, as observed by Kataria et al. (1997), Devi and Aramugam (1999), Nandadevi and Hosamani (2003), Patel et al. (2009). The direct effects of other characters were negligible. The residual effect of the path analysis was low (0.2274), suggesting inclusion of maximum green fruit yield among influencing characters in the present analysis.

Table 4. Estimates of genetic variability of 13 characters of chilli genotypes.

\begin{tabular}{|c|c|c|c|c|}
\hline Characters & PCV & GCV & $\begin{array}{l}\text { Heritability } \\
\text { (bs) }\end{array}$ & $\begin{array}{c}\text { Genetic } \\
\text { advance as } \\
\text { percentage } \\
\text { of mean }\end{array}$ \\
\hline & & $-\%$ & & $\%$ \\
\hline Days to $50 \%$ flowering & 27.97 & 27.47 & 96.50 & 25.33 \\
\hline Green fruit weight, $\mathrm{g}$ & 111.95 & 111.26 & 98.80 & 12.88 \\
\hline Green fruit length, $\mathrm{cm}$ & 38.85 & 38.75 & 99.50 & 6.05 \\
\hline Green fruit girth, $\mathrm{cm}$ & 89.76 & 48.93 & 96.70 & 1.18 \\
\hline Weight of red ripe fruit, $g$ & 112.02 & 111.93 & 99.80 & 11.31 \\
\hline Weight of dry fruit, $g$ & 111.63 & 110.97 & 98.80 & 2.57 \\
\hline Number of fruits per plant & 86.05 & 85.02 & 97.60 & 74.75 \\
\hline Number of seeds per fruit & 35.18 & 34.93 & 98.60 & 53.43 \\
\hline Green fruit yield per plant, $g$ & 50.87 & 50.58 & 99.00 & 122.97 \\
\hline Dry fruit yield per plant, $g$ & 50.87 & 50.60 & 99.00 & 24.59 \\
\hline Ascorbic acid content, mg $100 \mathrm{~g}^{-1}$ & 61.79 & 61.70 & 99.00 & 102.60 \\
\hline Oleoresin content, $\%$ & 40.57 & 40.29 & 98.60 & 17.55 \\
\hline Capsaicin content, $\%$ & 46.32 & 45.97 & 98.50 & 0.15 \\
\hline
\end{tabular}

PCV: Phenotypic coefficient of variation; GCV: Genotypic coefficient of variation.
Table 5. Genotypic and phenotypic correlations and direct effects of seven characters on green fruit yield per plant.

\begin{tabular}{lccc}
\hline Characters & $\begin{array}{c}\text { rg with } \\
\text { yield } \\
\text { per plant }\end{array}$ & $\begin{array}{c}\text { rp with } \\
\text { yield } \\
\text { per plant }\end{array}$ & $\begin{array}{c}\text { Direct effect } \\
\text { on yield } \\
\text { per plant }\end{array}$ \\
\hline Days to 50\% flowering & 0.459 & $0.462^{* *}$ & 0.001 \\
Green fruit weight, g & -0.112 & -0.114 & -0.182 \\
Green fruit length, cm & 0.121 & 0.123 & 0.472 \\
Green fruit girth, cm & -0.042 & -0.041 & 0.249 \\
Number of fruits per plant & 0.741 & $0.750^{* * *}$ & 0.979 \\
Number of seeds per fruit & -0.102 & -0.104 & -0.249 \\
Ascorbic acid content, mg100 g & 0.399 & $0.401^{* *}$ & 0.064 \\
\hline
\end{tabular}

"Significant at $5 \%$ level; ${ }^{* *}$ Significant at $1 \%$ level.

rg: Genotypic correlation coefficient; rp: phenotypic correlation coefficient; Residual effect: 0.2274 .

Table 6. Genotypic and phenotypic correlations and direct effects of seven characters on dry fruit yield per plant.

\begin{tabular}{lccc}
\hline Characters & $\begin{array}{c}\text { rg with } \\
\text { yield } \\
\text { per plant }\end{array}$ & $\begin{array}{c}\text { rp with } \\
\text { yield } \\
\text { per plant }\end{array}$ & $\begin{array}{c}\text { Direct effect } \\
\text { on yield } \\
\text { per plant }\end{array}$ \\
\hline Days to 50\% flowering & 0.459 & $0.462^{* *}$ & -0.070 \\
Weight of red ripe fruit, g & -0.133 & -0.134 & -1.528 \\
Weight of dry fruit, g & -0.113 & -0.115 & 1.939 \\
Number of fruits per plant & 0.741 & $0.750^{* *}$ & 0.860 \\
Number of seeds per fruit & -0.102 & -0.104 & -0.165 \\
Oleoresin content & -0.230 & -0.232 & -0.181 \\
Capsaicin content & -0.189 & -0.190 & -0.124 \\
\hline
\end{tabular}

${ }^{*}$ Significant at $5 \%$ level; ${ }^{* *}$ Significant at $1 \%$ level.

rg: Genotypic correlation coefficient; rp: Phenotypic correlation coefficient; Residual effect: 0.246 .

Regarding dry fruit yield per plant, there were highly positive direct effects on this trait shown by the characters viz. weight of dry fruit and number of fruits per plant, as observed by Natarajan et al. (1993), Devi and Aramugam (1999), Singh and Singh (2004). Low residual effect (0.2464) of the path analysis suggested inclusion of maximum dry fruit yield as an influencing character in the present analysis.

Although days to $50 \%$ flowering showed a positive significant correlation, the direct effect on green and dry fruit yield per plant was negligible. Thus, this trait may not be considered a reliable selection index. On the other hand, although green fruit length and weight of dry fruit showed negative associations with green and dry fruit yield of chillies, respectively, their direct effects were highly positive. Selection based on these characters could be beneficial for yield improvement of both green and dry chillies.

\section{CONCLUSION}

Wide variability has been found in different quantitative and qualitative traits of chilli grown in Eastern India. Most of the genotypes under study belong to Capsicum annuum. Some of the genotypes ('Chaitali Pointed' and 'BC CH Sel-4') possess high yield, with qualities suitable for use as both green and dry chilli. This information will provide breeders with the ability to develop desirable types having high yield and better nutritional profiles. From the combing study of GCV, PCV, heritability, genetic advance, correlation and path coefficient, two 
characters, namely number of fruits/plant and green fruit length, were found to be the most important selection indices of green chilli, whereas weight of dry fruit and number of fruits/plant were identified as most important selection indices of dry chilli.

Diversidad de recursos genéticos y análisis de asociación genética de ajíes verdes y secos del Este de India. El ají (Capsicum annuum L.) es considerado como uno de los principales cultivos comerciales de vegetales y especias a nivel mundial. La máxima diversidad puede ser observada entre los cultivares y razas disponibles en India con respecto a forma, tamaño, producción, calidad, y otros rasgos. Este experimento se realizó para identificar la variedad de ají más promisoria y apropiada para fruto verde y seco, para estudiar la variabilidad genética para diferentes rasgos y evaluar la asociación de diferentes rasgos productivos con el rendimiento de ají verde y seco. Treinta y cuatro genotipos se caracterizaron durante un período de 2 años. La mayoría de los genotipos poseía constelación de caracteres de C. annuиm. Dos genotipos, 'Chaitali Pointed' y 'BC CH Sel-4' fueron los más promisorios para rendimiento de fruto verde $(272,79 \mathrm{~g}$, $221,10 \mathrm{~g}$ por planta) y de fruto seco $(54,56 \mathrm{~g}, 44,44 \mathrm{~g}$ por planta). Los valores de coeficiente de variación fenotípica y genotípica se consideraron altos para peso de fruto verde $(119,95 \%, 111,26 \%)$, circunferencia fruto verde $(89,76 \%$, $48,93 \%)$, peso de fruto maduro rojo $(112,02 \%, 111,93 \%)$, peso de fruto seco $(111,63 \%, 110,97 \%)$ y número de frutos por planta $(86,05 \%, 85,02 \%)$. Rendimiento de fruto verde, contenido de ácido ascórbico, y número de frutos por planta también mostraron heredabilidad en sentido amplio y avance genético altos. Para el estudio de correlación y análisis de coeficientes, los índices de selección más importantes fueron número de frutos por planta y longitud de fruto verde para ají verde, y peso de fruto seco y número de frutos por planta para ají seco.

Palabras clave: rasgos cuantitativos, rasgos cualitativos, variabilidad genética, heredabilidad, índice de selección, Capsicum annuит.

\section{LITERATURE CITED}

Bandale, V.W., M.R. Palsuledesai, S.G. Bhave, S.S. Sawant, and S. Desai. 2006. Genetic evaluation of some economical traits in chilli (Capsicum annuum L.) in Konkan region of Maharashtra. Crop Research Hissar 31(3):401-403.

Bhagyalakshmi, P.V., C. Ravishankar, D. Subrahmanyam, and V.G. Babu. 1990. Study on heritability, genetic advance and character association in chilli (Capsicum annuum L.). South Indian Horticulture 38:15-17.

Bhattacharya, A., A. Chattopadhyay, D. Mazumdar, A. Chakravarty, and S. Pal. 2010. Antioxidant constituents and enzyme activities in chilli peppers. International Journal of Vegetable Science 16(3):201-211.

Bose, T.K., T.K. Maity, V.A. Parthasarathy, and M.G. Som. 2003. Vegetable crops. 668 p. Naya Udyog, Kolkata, India.

Bosland, P.W., and E.J. Votava. 1999. Peppers: Vegetables and spice capsicums. 250 p. CABI Publishing, Wallingford, UK.

Burton, G.W. 1952. Quantitative inheritance in grasses. p. 277-283.
Proceeding $6^{\text {th }}$ International Grassland Congress, Pennsylvania. 17-23 August. Pennsylvania State College, State College, Pennsylvania, USA.

Casanas, R., M. Gonzalez, E. Rodriguez, A. Marrero, and C. Diaz. 2002. Chemometric studies of chemical compounds in five cultivars of potatoes from Tenerife. Journal of Agricultural and Food Chemistry 50:2076-2082.

Chandra, A., B.K. Verma, and G. Satpute. 1990. Evaluation of selected chilli lines (Capsicum annuum L.). Vegetable Science 17:105-107.

Das, S., and K.R. Maurya. 2004. Heritability study in chilli. Journal of Applied Biology 14:22-23.

Devi, D.S., and R. Aramugam. 1999. Correlation and path coefficient analysis in chilli (Capsicum annuиm L.). Crop Research Hissar 17:90-93.

Dewey, D.R., and H.K. Lu. 1959. A correlation and path co-efficient analysis of component of crested wheat grass production. Agronomy Journal 51:515-518.

Gogoi, D., and B.P. Gautam. 2002. Variability, heritability and genetic advance in chilli (Capsicum spp.) Agricultural Science Digest 22:102-104.

Gomez-Fuentes, and W.M. Canessa. 1988. Preliminary survey of chili cultivars (Capsicum spp.). Capsicum and Egg Plant Newsletter 7:47-48.

Hanson, C.H., H.F. Robinson, and R.E. Comstock 1956. Biometrical studies of yield in segregating population of Korean lespedza. Agronomy Journal 48:268-272.

Hazra, P., A. Chattopadhyay, K. Karmakar, and S. Dutta. 2011. Modern technology in vegetable production. p. 478. New India Publishing Agency, New Delhi, India.

Hundal, J.S. 2000. Double chilli yield by growing hybrid varieties. Spice India (October Issue): 17-20.

Johnson, H.W., H.F. Rabinson, and R.E. Comstock. 1955. Genotypic and phenotypic correlation in soybean and their implication in selection. Agronomy Journal 47:477-483.

Kataria, G.J., H.M. Pandey, and M.A. Vaddaria. 1997. Genetic variability, heritability and genetic advance of various polygenic traits in capsicum. Gujarat Agricultural University Research Journal 22(2):18-21.

Khadi, B.M., J.V. Goud, and V.B. Patil 1987. Variation in ascorbic acid and mineral content in fruit and some varieties of Chilli (Capsicum annuum L.). Plant Food for Human Nutrition 37:9-15.

Khurana, S.C., M.L. Pandita, K.K. Thakral, and C.B. Singh. 2003. Correlation and path analysis studies in chilli. Maharashtra Journal of Horticulture 7:70-80.

Kogure, K., S. Goto, M. Nishimura, M. Yasumoto, K. Abe, and L. Ohiwa. 2002. Mechanism of potent antiperoxidative effect of capsaicin. Biochimica et Biophysica Acta 1573:84-92.

Kumar, B.K., A.D. Munshi, S. Joshi, and C. Kaur. 2003. Correlation and path coefficient analysis for yield and biochemical characters in chilli. Capsicum and Egg Plant Newsletter 22:67-70.

Nandadevi, R., and R.M. Hosamani. 2003. Variability, correlation and path analysis in Kharif chilli genotypes for different characters. Capsicum and Egg Plant Newsletter 22:43-46.

Natarajan, S., P. Gomathinayagam, and P.M.M. David. 1993. Studies in variability in chilli. Madras Agricultural Journal 80(7):388-390.

Patel, P.N., R.S. Fougat, and N. Sasidharan. 2009. Studies on genetic variability, correlation and path analysis in chillies (Capsicum annuum L.). Research on Crops 10(3):626-631.

Prabhakaran, T.S., S. Natarajan, and D. Veeraragavathatham. 2004. Studies on genetic variability and genetic advance in chilli (Capsicum annuиm L.). South Indian Horticulture 52(1-6):70-72.

Ranganna, S. 1986. Handbook of analysis and quality control for fruit and vegetable products. $2^{\text {nd }}$ ed. Tata McGraw Hill Publ. Com., New Delhi, India.

Rani, P.U. 1997. Evaluation of chilli (Capsicum annuum L.) for root and their relation with yield. Mysore Journal of Agricultural Science 31:51-59.

Rani, P.U. 2001. Evaluation germplasm for fruit surface area in chilli (Capsicum annuиm L.). Crop Research Hissar 21:168-173. 
Rani, K., S. Natarajan, and S. Thamburaj. 1996. Correlation and path analysis in chilli (Capsicum annuum L.). South Indian Horticulture 44(1-2):8-11.

Reddy, K.M., A.A. Deshpande, and A.T. Sadashiva. 2002. Cytoplasmic genetic male sterility in chilli (Capsicum annuиm L.). Indian Journal of Genetics 62(4):363-364.

Reddy, A.C.P., and B.R. Lokesh. 1992. Changes in catalase and ascorbic acid oxidase activity in response to lead nitrate treatments. Indian Journal of Plant Physiology 34:143-146.

Sadasivam, S., and A. Manickam. 1992. Biochemical methods for agricultural sciences. Wiley Eastern Ltd., New Delhi, India.

Sheela, K.B., T.E. George, and K.V. Peter. 2004. Morphological and biochemical traits of selected accessions of bird pepper (Capsicum frutescens L.). Capsicum and Eggplant Newsletter 23:33-36.

Singh, M.D., J.M. Laisharam, and T. Bhagirah. 2005. Genetic variability in local chillies (Capsicum aпnиит L.) of Manipur. Indian Journal of Horticulture 62(2):203-205.

Singh, M.D., and N.G. Singh. 2004. Correlation and path analysis studies in selected local chillies (Capsicum annuиm L.) of Pasighat. Environment and Ecology 22(Suppl. 4):672-675.

Tembhurne, B.V., R. Revanappa, and P. Kuchanur. 2008. Varietal performance, genetic variability and correlation studies in chilli (Capsicum annuum L.). Karnataka Journal of Agricultural Science 21(4):541-543.

Varkey, J., M.P. Saiyed, J.S. Patel, and D.B. Patel. 2005. Genetic variability and heritability in chilli. Journal of Maharashtra Agriculture University 30:346-347.

Wasule, J.H., J.N. Parmar, N.R. Potdukhe, and D.T. Deshmukh 2007. Variability studies in chilli. Annals of Plant Physiology 18:187-191. 